\title{
Article
}

\section{Fiji's coup culture 1987-2006: A media perspective}

\section{ABSIRACI}

Since attaining independence from Britain in 1970, Fiji enjoyed a period of 'multiracial peace' for 17 years under Ratu Sir Kamisese Mara and this gave the country the utopian slogan: 'Fiji-the way the world should be.' But was this really so? Beneath the notion of peace, democracy and racial unity was a racial volcano that erupted when democracy took another turn. Subsequent to the defeat of the chiefly-led Alliance Party in the 1987 election, a third-ranking military officer, Sitiveni Rabuka, staged a coup to topple a Fijian-led but Indian-dominated government. He later handed the controls back to indigenous Fijians. Since then, Fiji has never really tasted any long-lasting political peace, democracy or stability. Despite two constitutions and some five elections since the first coup, the Western concept of stable democracy has eluded Fiji. It has had four coups since 1987 and this notoriety relegated it to rogue state status with a 'coup culture', or as some academics and journalists have described it, became 'coup coup land'. This article examines some issues relating to the prevalence of the coup culture in Fiji and, views them in the light of media coverage.

Keywords: coup culture, decolonisation, democracy, ethno-nationalism, history, indigenous, journalism ethics, military coups, Stockholm syndrome

\section{THAKUR RANJIT SINGH AUT University}

$\mathrm{P}$ RIOR TO Fiji being ceded to Great Britain in 1874, the then 'king' of Fiji and Fijian paramount chief, Ratu Seru Cakobau, was reported to have said: "If matters remain as they are, Fiji will become like a piece of driftwood on the sea, and be picked up by the first passerby' (Scarr, 
1970, p. 123). It was this thought of Fiji going into undesirable hands, among others, that prompted Fijian chiefs to cede Fiji to Great Britain.

Fiji became a British Crown Colony on 10 October 1874 when growing European pressure on Fijian land and labour and their entanglement in internal Fijian rivalry for power and political ascendancy forced the self-styled Tui Viti, Ratu Seru Cakobau, to cede Fiji Islands to the United Kingdom. (Lal, 2010, p. 67)

Lal (2010) refers to this as an unconditional transfer that was solemnised in the 'Deed of Cession' which outlined what chiefs had ceded or did not cede to the Crown, and how and in what way Fijian interests would remain 'paramount' in Fiji (p. 67). It was the Independence Order of 1970 which formally brought this cession to an end nearly a century later.

The early history suggests that Melanesian Fijians were fierce fighting people who had strong tribal affiliations and loyalties, and who had experience in espionage and coups to take over the ruling of the islands. And that tendency appeared to have lingered on.

It seems this cultural trait came into action when the Fijian chiefs lost power in 1987. The early history of the Fijians, sees their regimes littered with episodes of tribal wars, coups and counter coups. Therefore one would not be incorrect in suggesting the term 'coup culture' for Fiji, as indeed it had been part of the Fijian culture long before the arrival of the missionaries and Christianity in the 18th and 19th centuries. In that spirit, this article also adopts the term 'coup culture' which is deemed appropriate given the prevalence of coups in the early history of the indigenous Fijians.

This article examines the reasons for a coup culture in Fiji and attempts to dig slightly deeper to try to fathom how a greater degree of analytical journalism may have been able to provide the underlying reasons for the fall of democracy in Fiji to military coups since 1987.

\section{The 1987 Coups: Sitiveni Rabuka}

Hansard records for 'treason at ten' on 14 May 1987 documented the following, just as one Member of Parliament who had the floor asked the speaker: 'How much time do I have, Sir,' and the reply came 'Press on regardless' when masked soldiers came into the Parliament: 
Sit down everybody, sit down. This is a take-over. Ladies and gentlemen, this is a military take-over. We apologise for any inconvenience caused. You are requested to stay cool, stay down and listen to what we are going to tell you. Please stay calm, ladies and gentlemen. $\mathrm{Mr}$ Prime Minister, please lead your team down to the right. Policeman, keep the passage clear. Stay down, remain calm. Mr Prime Minister, Sir, will you lead your team now.' (Scarr, 1988, p. 70)

Robie (1989) summed up that the demise of democracy in Fiji actually took place at 10.04 am, 14 May 1987 on an otherwise auspicious day. It was the 108th anniversary of the first arrival of the indentured Indian labourers who, in a twist of irony, were looking for a new life of hope (p. 219).

Then editor of The Fiji Times, Vijendra Kumar (2004) has also related his experience. He was in Raki Raki in the western part of Viti Levu when he heard the news over the radio. He rushed back to the office, attended the press conference where the reason for the coup was given as an act by the military to stop wholesale violence in Fiji by militant groups. The Fiji Times was published next day, but was shut down after the following day, 16 May 1987. Robie (2004) tells of the humiliation of Kumar when he was led out of the office of the paper at gunpoint, and this was related by one of his staff, Eroni Volavola, a sports reporter (later to become media officer for Fiji's Lands Transport Authority) who then was in the army's Territorial Force. (p. 96). After shutting down for a month, The Fiji Times resumed publishing with very controlled news. (The Fiji Sun, the other daily, did not meet the same fate. It closed down for good, as it refused to operate under any form of censorship). After continuous harassment for four years, Kumar (2004) decided to leave Fiji and settled in Brisbane, Australia (p. 323).

Robie (1989) in his book Blood on their Banner had been critical of the local media during the Rabuka regime in and after the 1987 event. A subheading in a chapter: 'A compromised media' is self-evident that media was seen to be wanting (pp. 238-241). While the military under Rabuka was negotiating for huge military expansion under French aid and a soft loan, including planned construction of a naval base and purchase of helicopters as part of the surveillance division, sections of the Fiji media bypassed such major developments as not news and little was reported. What was ironic was that somebody who had committed treason in Fiji for preserving indigenous rights was alienating Kanaks and Tahitian nationalists through his 'marriage' with 
the French government, which was then denying its indigenous people the right of self-determination (p. 238). Even the allegations that French aid was diverted to the military failed to attract the attention of the Fiji media. Robie was critical of the sections of the Fiji media for allegedly compromising the principles of journalism:

It is indicative of just how complete was Rabuka's control and manipulation on the news media that these developments passed generally without comment or criticism. The Fijian news media, particularly Radio Fiji and the vernacular newspaper Nai Lalakai (part of The Fiji Times), justified the military build-up as a measure to counter supposed internal and external threats. In one Nai Lalakai article prepared by the military, democracy was dismissed as 'trickery of the devil' and the Fijians were urged to ignore the educated elite. (Robie, 1989, p. 239)

Some senior Fijian journalists were named as alleged sympathisers and propagandists for the Taukei Movement while others were prepared to stick to the principles of fair journalism (Ibid). The old Fiji Sun, which decided to close down, was hailed as a brave paper that was prepared to stand up for truth and social justice. Rabuka not only manipulated and used media during the coup, but he began his coup with the use of the government's information ministry's news mechanism.

The then Permanent Secretary for Information in the Fiji government, Peter Thomson (1999) relates a somewhat lighter and hilarious incident on the day of the coup when he was sharing grog (kava) in a nearby office which was next to Parliament. He saw soldiers and dismissed them as being on some sort of civil defence exercise. Later, while deep in conversation, the door of the office was kicked open and gas-masked soldiers burst into the room, formed half a circle around the open door and trained their guns on their stunned gathering. In stepped Lieutenant-Colonel Sitiveni Rabuka, wearing a grey lounge suit with sulu vakataga, polished military sandals and striped tie, and sporting a handlebar moustache. He asked for Peter Thomson, with the audience staring in stunned silence. When identified, Thomson was directed back to his office and Rabuka ordered him to issue a press release. He related that Rabuka dictated while his fingers flew across the paper,

The Royal Fiji Military Forces have taken control of the Fiji government to prevent any further disturbance and bloodshed in the country. 
I am on my way to Government House to seek recognition. I ask the public to remain calm and continue with their daily work. In particular, I ask that Fijian community do not take advantage of the situation. (Thomson, 1989, p. 13)

This message was broadcast on Radio Fiji and circulated to other media outlets. So was revived the coup culture, an action that was last carried out by Seru Cakobau in 1830s to take control from his opponents. Unbeknown to all, this was to be repeated over and over again, and would be adopted as the term applied today - the coup culture of Fiji.

\section{Did Rabuka have any other way in May 1987?}

Subsequent to the coup that Rabuka executed in 1987, he wrote his first book, No Other Way and gave the reasons why he did what he did - as he had no other way. From an analytical perspective, did he have any other way in $1987 ?$

Perhaps with the benefit of hindsight, it can now be confidently said that Rabuka and the military would have been right if they were ready to crush Fijian nationalism and tribalism in 1987 to instil respect for the majority decision and democracy at an earlier stage in Fiji's history. Succumbing to the nationalists' demand was the first step in giving credence to the Fijian coup prevalent during the 1800 s where might was seen as right. The Bavadra government, after one month in office was becoming popular and already attracting support from all quarters. If the military had the will, like the then Commander, Ratu Epeli Nailatikau (now the President of Fiji) to support democracy, Fiji's history may have been quite different today. Some commentators even speculated that Fiji may have been comparable to the Asian tigers, such as Thailand, Malaysia, South Korea, Taiwan and Singapore. But, as has been suspected all along, Rabuka's aim was to give Fiji back to the Fijian chiefs, especially the eastern chiefs in the Alliance Party who had just lost an election and majority support.

Had Rabuka allowed his military commander to support democracy and provide security from the internal threats to the Bavadra government, then perhaps he would have been instrumental in avoiding the 2000 Speight coup, and the current Bainimarama coup where the military is doing exactly what Rabuka's excuse was for executing the 1987 coup. Rabuka's action in 1987 was ammunition for people like Speight and the chiefs who supported him, 
who thought if Rabuka did it in 1987 and gained handsomely through his treasonous act, then why should they not try to achieve a similar result. Naidu (2007) of the University of the South Pacific (USP) agrees that what Speight did was imitate Rabuka but failed because of the lack of support from the military and the chiefs (p. 33). Robie (2000) agreed that while both Rabuka and Speight had conducted both coups for 'indigenous Fijian supremacy', Speight was out to finish the unfinished business of 'Fijianisation' of Fiji that Rabuka had failed to achieve (p. 2). Had Rabuka allowed history to take its course without military intervention, perhaps Bainimarama might not have been placed in a position as the new commander to act as he did after seeing the poor governance, corruption and racism under the guise of a democracy which the military was seen to be protecting, enhancing and promoting. Bainimarama may not have had to use the military against the Fijians, which was the reason for Rabuka to carry out his first coup in 1987. It is now seen as an exercise in futility. The November 2000 mutiny, which many suspect was instigated by Rabuka along with the convicted Naitasiri chief Ratu Inoke Takiveikata and other chiefs, ended with eight soldiers and rebels being killed (Bhim, 2000, p. 128): 'Altogether eight soldiers, two policeman and two rebels were killed in the coup and the mutiny of 2000' (Naidu, p. 31). This led to so much division, bad blood and heartbreak in the army, which previously had been a sacred institution for the Fijian community.

The current demise of the Great Council of Chiefs, curbing of the Methodist Church and the restructure and reform of other Fijian institutions is because of that early action by Rabuka in 1987. If the Fijian military is today being used against the Fijians to crush their racism and ethno-nationalism, it is also because of his action.

While history has demonstrated that he was wrong in 1987, it also reveals after all, he had not been such a bad person. He had admitted, through his subsequent actions, that his ethno-nationalism of 1987 was wrong. He redeemed his coups by siding with Jai Ram Reddy and the National Federation Party (NFP) in delivering Fiji the 1997 multiracial constitution. In his quest to promote and revive multiracialism, he sacrificed his political career by siding with an Indo-Fijian party (NFP). He was dumped and his chief-sponsored party, the SVT, lost heavily in the 1999 elections. The Fiji Labour Party (FLP) and its coalition partners were the beneficiaries and, consequently, they enjoyed a landslide victory. It is said that both the Fijians and the Indo-Fijians are now 
paying a heavy price for not embracing multiracialism when the Rabuka-Reddy team offered it to them during the 1999 elections. Both these leaders paid the ultimate price for experimenting with multiracialism because the people still voted on racial lines and dumped their respective parties. Jai Ram Reddy's NFP failed to win a single seat.

One of the architects of the 1997 Constitution, Professor Brij Lal (2010), summed this up in his book on Jai Ram Reddy, In the Eye of the Storm:

\begin{abstract}
Reddy understood Rabuka's predicament and refused to take advantage of his numerous political misfortunes. Perhaps somewhere deep in his heart he even liked the man for who he was: sometimes misguided, sometimes evasive, a shrewd political animal, but essentially a decent, forgiving, warm-hearted human being. Had the Rabuka-Reddy political project succeeded, Fiji would almost certainly have been spared much of the agony and trauma it encountered in the years ahead. So while the Chief [Mara] and the Indian [Reddy] could not connect; the Commoner [Rabuka] and the Indian did. (Lal, 2010, p. 9)
\end{abstract}

Rabuka and Reddy have both since retired from political life. Jai Ram Reddy now resides in Auckland, New Zealand, while Rabuka still lives in Fiji outside the political or leadership limelight.

\title{
A racially-balanced military: Panacea to Fiji's problems?
}

The other issue relates to the composition, or rather the racial makeup of Fiji's military. A question here relates to the reluctance of the Fijians and the British colonials to allow the Indians into the military. What might have been the history of Fiji if the Indians had been encouraged and even forced to join the army during the two world wars? The answer perhaps lies in the next question and answer.

Why did Papua New Guinea and India, despite being so divided on regional, provincial, language, cultural and ethnic lines, have little chance of a successful racially-instituted or ethno-motivated military coup as Fiji did?

The answer is because their military do not have the type of racial, ethnic, traditional or religious polarisation that Fiji military has. In those countries the diverse make-up of the soldiers would thwart, discourage and even prevent any uprising based on racial, religious and regional superiority.

If the Fiji military in 1987 had, say 30 to 50 percent Indo-Fijian soldiers 
distributed equally in all the ranks, would Rabuka still have been able to topple the then Commander and institute a racially-motivated coup?

The chances would have been slim, and may even have resulted in a mutiny as the comradeship in the military often transcends race, and a better alternative than treason could have been possible. In addition, it may have been difficult to keep such a plot secret in a racially-balanced army

The bottom line is that, to remove the coup culture in Fiji, the military in Fiji should embark on racial balancing of the Fiji Military Forces and encourage Indo-Fijians to join military service. Such an exercise may be implemented over a long period of time based on natural attrition of the current soldiers in the army. There is no shortage of Indo-Fijians willing to join. The only problem is that, like in colonial days, they are not accepted, and in turn are blamed for lacking patriotism or the right physical build. On the excuse of smaller stature, tiny Ghurkhas and relatively smaller built Asian soldiers are competitive with heavily built 'islanders'. Similarly, the slightly built Japanese soldiers during the Second World War created havoc among countries which had soldiers of bigger physical stature. What this means is that to possess military prowess and courage, size does not matter. For Fiji to deny Indo-Fijians recruitment in its military because of size and other reasons defies logic and historical backing.

The absence of Indo-Fijians in the army was raised.... 'Anybody can be accepted into the army,' Colonel Paul Manueli, then head of the Fiji Military Forces, said. 'But we do not provide special meals.' It seemed a lame excuse, nothing more. Why not, it was asked, when exceptions were made for Fijians in other areas of public service? What about the Ghurkhas, it was asked, who did not eat beef? The message, distilled to its bare essence, was simple: that the Fijian - dominated Alliance party would never relinquish control of the military, or dilute the Fijians presence in it, which it saw as the ultimate bastion of power for the Fijian establishment. (Lal, 2010, p. 146)

\section{The adequacy of the 1970 and 1997 Constitutions}

This has been a persistent issue for decades because successive ethno-nationalists (including Sitiveni Rabuka, George Speight and their supporters) have used the excuse of the inadequacy of the 1970 and 1997 constitutions to carry out respective coups against successive democratic governments. Claiming to carry out the coups in the name of protecting Fijian interests, 
they fail to inform how these documents were defective or inadequate in protecting indigenous interests. This subject has also not been fully pursued through any media scrutiny or analysis, which is this article's third issue for discussion.

The preamble to Qarase's 2005 ill-conceived Reconciliation, Tolerance and Unity Bill (RTU), as cited by Singh (2006) read:

And whereas the political events of 1987 and 2000 were occasioned by a widespread belief among indigenous Fijians that the 1970 and 1997 Constitutions were inadequate effectively to protect and preserve their rights and interests, their values, traditions, customs, way of life and economic wellbeing ... (Singh, 2006, p. 357)

In fact, Qarase was trying to pass a law based on misrepresentation and this thinking has been used in the past to rationalise and justify the coups of 1987 and 2000. It is evident that the Fiji media have not dug deeper to find out the truth. This practice of the Qarase regime to ought to have been scrutinised by the Fiji media.

Sir Vijay R. Singh, the first Indo-Fijian knight and statesman and former Attorney-General in Ratu Mara's Alliance government, raised some valid questions:

Is it ever possible to reach an enduring agreement with Fijians on any important issue? Or will they renounce every solemn settlement whenever the next false prophet emerges from the woodworks? (Singh, 2006)

The historical and founding constitution (1970) after independence was arrived at after free negotiations and with the consent of all the stakeholders. It was not only unanimously approved by the Great Council of Chiefs but also endorsed by the British government on behalf of the Crown. The Fijian chiefs, including Ratu George Cakobau and Losalini Dovi, the two nominees of the Great Council of Chiefs and the Legislative Council unanimously approved the 1970 Constitution when it was tabled for formal consideration.

Lal (2010) cited Jai Ram Reddy, the former Leader of the Opposition, and the NFP through a speech Reddy delivered in Cuvu, Sigatoka, during the NFP Convention address of 1981. In allaying fears about the security of Fijian land and the protection provided by the 1970 Constitution, Reddy said: 
And the supreme law of the land is the Constitution of Fiji. That Constitution protects the ownership of all land and especially Fijian land in a way which is probably unique in the world. Section 63 of the Constitution states that any law affecting Fijian land cannot be changed unless two-thirds of the members of the House of Representatives and the Senate and six out of eight nominees of the Great Council of Chiefs vote in favour of the change. In other words, three nominees of the Great Council of Chiefs can veto any proposed change. (Lal, 2010, p. 179)

Several paradoxes about the coups were never corrected by Fiji media. The 1970 Constitution was good, acceptable, safe and very suitable in the 17 years during the rule of Ratu Mara's Alliance Party. Yet it was only found to be deficient and defective when the Alliance lost power to Dr Bavadra in 1987 and the power shifted to the West.

It took a third-ranking army officer, a commoner, Lieutenant-Colonel Sitiveni Rabuka, to tell the nation that the Constitution was defective. Sir Vijay Singh (2006) questions: Where were the Fijian political leaders, academics or their many institutions, including the Great Council of Chiefs? (p. 358). This paradox continues, because the Great Council of Chiefs supported Rabuka's treasonous act without protest or objections after the event. Not only that, they made Rabuka, a commoner, the council's life member. This honour had nerver been bestowed on anyone before.

Now to the 1997 Constitution: This was approved by the Great Council of Chiefs. In addition to this the members of both the upper and the lower houses (the Parliament and the Senate) unanimously gave their approval. More importantly, all the Fijian members did so as well.

It took a bankrupt and failed businessman, not even a full Fijian, to inform the Fijian people and their chiefs of the inadequacies of the unanimouslyapproved 1997 Constitution that had brought an Indo-Fijian to the prime ministership. The Great Council of Chiefs, which has since being disbanded by Bainimarama as a institution imposed by the British, had supported both Speight's as well as Rabuka's respective coups, hence losing its conventional apolitical, neutral and impartial stance.

The question arises over the unethical practices of the Qarase regime which introduced a Reconciliation Bill that referred to the "widespread belief among the indigenous Fijians that the 1970 and the 1997 Constitutions were inadequate to protect and preserve' Fijian heritage, including their land rights 
(p. 358). Qarase's SDL government had a great deal to answer. Singh (2006) questioned how and when were:

... those interests and rights threatened: Why and how the built-in protection of the 1970 and 1997 constitution was insufficient; what proposals had the Fijians made for the strengthening of those provisions etc? And equally importantly, how was the removal of Ratu Mara from the presidency a solution to the perceived problem? (Singh, 2006, p. 358)

Sir Vijay R. Singh, who had migrated to Brisbane, was supposed to launch his book in Suva in 2007 but was prevented from attending by the nationalist Taukei movement, the same supporters of Rabuka and Speight. Singh's writing and views about the hypocrisy of the Fijian leadership had made him unpopular with those who still believed might was right.

Fiji's history is a testimony to the fact that no Indian has deprived a single native landowner of a square metre of his land. This, however, cannot be said of the Anglo-Saxon colonialists. Instead it was Chaudhry, an Indo-Fijian Prime Minister who gave them back schedule A and B land which the colonial rulers had converted into state land and the Fijians' own leaders had for 130 years retained as such.

Among other things the purpose of bringing up this discussion was, as Singh's (2006) quotes noted here had intended, 'to stop the merchants of malice from spreading their litany of lies' (p. 359).

The merchants of malice continue to ply their wicked trade at every opportunity by maligning a whole race that is innocent of any wrongdoing against Fijian custom, tradition or their land. They need to be exposed to the cleansing light of truth; not tolerated in silence. (Singh, 2006, p. 359)

The purpose, in some small part, of this article, is to reveal the realities and show them in a light where they may never have been told by the Fiji media which lack analytical and investigative skills. It is not surprising that USP academic Professor Vijay Naidu has claimed that 'Fiji has never been a real democracy, it has been characterised by a "façade" of democracy" (Naidu, 2007, p. 24).

\section{Fiji media and the $\mathbf{2 0 0 6}$ military takeover}

One interesting point of discussion at this juncture is that generally media 
is referred to as the Fourth Estate, and one wonders where it was during all the time the military was challenging Qarase's government. Should they not have been at the forefront of reporting for good governance and been more vigilant and questioning as they were during Chaudhry's administration? Why had it gone mute? Was it because the media was controlled by Fijians and this power struggle was about Fijian control and a Fijian government and not an 'Indian' one?

The military coups d'état that the country has experienced over the last 20 years have been to Fiji's detriment. Coups up till the current one [2006] were designed to maintain chiefly power and to promote narrow ethnic interests that benefitted elements of an aspirant ethnic Fijian middle class and its business allies. (Naidu, 2007, p. 33)

There was much protest over the removal of the publishers of The Fiji Times and The Fiji Sun respectively. However, the Fiji media remained relatively quiet when the Deputy Director of Public Prosecutions was given his marching order, thus interfering in the post-coup judicial investigations. 'The government blocked the renewal of the contract of Australian prosecutor Peter Ridgeway, who has been successful in obtaining convictions of several putsch supporters' (Ibid, p. 31). This brings into question the role played by Fiji media in neither being analytical nor digging deeper on issues that were reportedly in play during Chaudhry's rule when even the smallest of internal government issues were dug up and exposed by an active media (Singh, 2011, p. 260).

Chaudhry had lodged a long list of polling discrepancies, both for the 2001 and 2006 elections (Chaudhry, 2007). To what extent did the media follow up to ensure Fiji had clean elections? How questioning were they of what the general public in the extremely long election queues saw as, an incompetent Supervisor of Elections office? What credibility did the overseas observer groups hold? Why did the international observer groups lack observers from India, Mauritius, Malaysia, Singapore and other Commonwealth countries going through ethnic, political and electoral issues and with similar historical backgrounds?

In earlier discussion, some important issues were raised about the 'merchants of malice' who were propagating misinformation. To what extent did the media take its role to advise the Fijians about the safety provisions of the 1970 
and 1997 constitutions? To what extent did they attempt to correct the misinformation spread by the ethno-nationalist elements in racial hate-speeches?

This author had given tips to the Fiji media on issues in relation to Qarase's Duavata Initiative, the business arm of Qarase's ruling SDL party and the affairs of the Fijian Holdings Limited where the elite Fijians were alleged to have profited from their strategic influential and leadership positions. However, it appears that the Fiji media had been reluctant to follow issues involving influential Fijians (Singh, 2011, pp. 243, 245-252).

There have been numerous, especially Indo-Fijian, commentators, including Sir Vijay Singh, who have questioned the irrationality coming from respective Fijian regimes. What steps did the media take to pick up on issues and conduct some in-depth analytical and investigative reporting to keep in line a regime which was seen as abusing its democratically-acquired status and which Bainimarama saw as a reason to remove a supposedly democratic Qarase's regime?

An important question is whether the Fiji media, in particular the dominant Fiji Times, been more responsible, more impartial, more balanced, and, ultimately, more questioning and investigative, in raising the issues of poor governance practised by Qarase and his SDL government, would the December 2006 takeover by Bainimarama have been avoided? Various research on the Fiji media, especially The Fiji Times, as outlined below, does raise some questions.

\section{Conclusion}

Research conducted by scholars and academics on the Fiji media in general, and The Fiji Times in particular, found the media wanting. Devi (1992) analysed the coverage of Fiji's 1992 general election under the racist 1990 Constitution and did an analysis of The Fiji Times and Daily Post. Gounder (2006) undertook an analysis of The Fiji Times to show how the media generated animosity and tension between the major ethnic groups there. Gounder (2006) conducted research on the coverage of George Speight's coup with content analysis of three print media and also ventured to gauge the Stockholm syndrome on reporters staying in Fiji's Parliament while covering the Speight takeover. Kiran (2005) conducted an analysis of coverage of Fiji's May 2000 political crisis by The Fiji Times. Obini (2000) analysed the news coverage by The Fiji Times leading up to George Speight's putsch and the demise of the Chaudhry government. This author (Singh, 2011) carried out 
a further in-depth content analysis of The Fiji Times to determine what role, if any, the newspaper played leading up to Speight coup in 2000. The common thread in all these research papers and theses is that they all were critical of the stance of The Fiji Times, which lacked the analytical articles and investigative calibre that may have spared the country numerous man-made disasters.

In a December 2010 symposium at USP, Professor Robie was cited by Shailendra Singh (2010) calling for greater responsibility of media in supporting democracy, a greater need for analytical articles and in-depth reporting and empowering the public through better reporting. While this was in the context of peace journalism and conflict resolution, such analytical and investigative reporting on the issues that have been covered above may have contributed to a better informed audience during the Fijian coups.

\section{References}

Chaudhry, M. (2007). Tainted election. In J. Fraenkel \& S. Firth (Eds.), From election to coup in Fiji: The 2006 campaign and its aftermath. (pp. 347-364). Canberra, Australia: ANU E Press/Asia Pacific Press; IPS.

Devi, P. (1992). Print media in Fiji: Fostering democracy or ethnocracy? Fiji Institute of Applied Studies, Research Report No 2, Suva, Fiji.

Gaunder, P. (2006). Media and peace: The Fiji example: Working paper No 14. Centre for Peace Studies, University of Auckland, Auckland, New Zealand.

Gounder, C. (2006). The Fiji 2000 coup: A media analysis: Unpublished Master's thesis. Auckland University of Technology Auckland, New Zealand.

Kiran, S. S. (2005). An analysis of the reportage of Fiji's May 2000 political crisis in The Fiji Times. Unpublished Master's thesis. Department of Literature and Language, The University of the South Pacific, Suva, Fiji.

Kumar, V. (2004). Goodbye to paradise. In B. V. Lal (Ed.), Bittersweet: The IndoFijian experience (pp. 323-336). Canberra, Australia: Pandanus Books.

Lal, B. V. (2010). In the eye of the storm: Jai Ram Reddy and the politics of postcolonial Fiji. Canberra, Australia: ANU E Press.

Naidu, V. (2007). Coups in Fiji: Seesawing democratic multiracialism and ethnonationalist extremism. Devforum, 26: 24-33.

Obini, N. (2000). Coup 2000: Responsible journalism: The Fiji Times?. Unpublished thesis. Centre for Development Studies, Department of Sociology, University of the South Pacific, Suva, Fiji.

Robie, D. (1989). Blood on their banner: Nationalist struggles in the South Pacific. Leichhardt, NSW., Australia: Pluto Press.

Robie, D. (2000). Taukei takeover: The media anatomy of a coup. Australian Journalism Review, 22(2), 1-16.

180 PACIFIC JOURNALISM REVIEW 18 (2) 2012 
Robie, D. (2004). Mekim nius: South Pacific media, politics and education. Suva, Fiji Islands: USP Book Centre; AUT Press: South Pacific Books.

Scarr, D. (1970). Cakobau and Ma'afu: Contenders for pre-eminence in Fiji. In J. W. Davidson \& D. Scarr (Eds.), Pacific islands portraits (pp. 95-126). Canberra, Australia: Australian National University Press.

Scarr, D. (1988). Fiji: Politics of illusion. Kensington N.S.W., Australia: New South Wales University Press.

Singh, S. (2010). Media educator calls for 'watchdog plus' role to boost democracy. Retrieved October 20, 2010, from Pacific Media Centre http://www.pmc.aut. ac.nz/articles/media-educator-calls-\%E2\%80\%98watchdog-plus\%E2\%80\%99role-boost-democracy

Singh, S. V. R. (2006). Merchants of malice. In S. V. R. Singh (Ed.), Speaking out: Commentary on political, social and economic issues in Fiji during the decade 1995-2005 (pp. 357-361). Canberra, A.C. T. Australia: Knightbrook Publications. Singh, T. R. (2011) The 2000 Speight coup in Fiji: An analysis of the role of The Fiji Times and the impact of partisan media: Unpublished Master's thesis, Auckland, New Zealand: School of Communication Studies, AUT University.

Thomson, P. (1999). Kava in the blood: A personal and political memoir from the heart of Fiji. Auckland, New Zealand: Tandem Press.

Thakur Ranjit Singh is 2009/2010 AUT/Pacific Islands Media Association (PIMA) Pasifika Postgraduate scholar in communication Studies. He is former a publisher of Fiji's Daily Post newspaper. This is a modified version of a paper he originally presented at AUT's Media, Investigative Journalism and Technology (MIJT) conference on 5/6 December 2010 at AUT University, Auckland, New Zealand.

thakurji@xtra.co.nz 
Copyright of Pacific Journalism Review is the property of Auckland University of Technology and its content may not be copied or emailed to multiple sites or posted to a listserv without the copyright holder's express written permission. However, users may print, download, or email articles for individual use.

http://www.aut.ac.nz/depts/commstud/journ/pjrsubs.shtml 